\title{
İşletmelerde Kurumsal Risk Yönetimi ve İç Denetime Farklı Bir Bakış Açısı: 5S Uygulaması
}

\section{A Different Perspective of Enterprise Risk Management and Internal Audit in Companies: 5S Implementation}

\author{
Serdan Öner ${ }^{1} \oplus$, Burcu Adiloğlu² ${ }^{\circledR}$ \\ 'İç Denetim Müdürü, İstanbul, Türkiye \\ ${ }^{2}$ Doç. Dr. İstanbul Üniversitesi İşletme Fakültesi, Muhasebe Anabilim Dalı, İstanbul, Türkiye \\ ORCID: S.Ö. 0000-0003-3162-5065; B.A. 0000-0001-9680-1408
}

\begin{abstract}
ÖZ
İç denetim mesleği, ilk ortaya çıktığı yıllardan bu yana iş dünyasında yaşanan gelişmeler ve organizasyonların ihtiyaçları doğrultusunda şekillenmiş ve gelişmiştir. Risk odaklı denetim yaklaşımı ile iç denetimin riske ve risk yönetiminin bir parçası olan kontrollere bakış açısı değişmiş ve iç denetçilere daha fazla değer yaratmaları için bir firsat sunulmuştur.

$\mathrm{Bu}$ çalışmada kurumsal risk yönetiminin etkinliğini sağlamada iç denetimin rolü temel kavramlarıyla ayrıntılı olarak açıklanmıştır. Ardından organizasyonlarda kaliteli bir çalışma düzeni oluşturmak ve faaliyetlerin sürekliliğini sağlamak için geliştirilen bir teknik olan $5 \mathrm{~S}$ uygulamasının işletmenin risk yönetim sürecindeki yeri belirtilmiştir. Bu kapsamda bir işletmede iç denetim faaliyetleri kapsamında bir $5 \mathrm{~S}$ uygulaması örnek olarak sunulmuştur. Anahtar kelimeler: İç Denetim, Risk Yönetimi, Kurumsal Risk Yönetimi, 5S Uygulaması
\end{abstract}

\section{ABSTRACT}

The internal audit profession has developed and taken shape according to the needs of organizations and developments in the business world since its first appeared. Views on internal auditing regarding the risk and controls which are parts of risk management changed significantly with the risk-based auditing approach and internal auditors were presented with an opportunity to create more value.

In this study, the basic concepts of the role of the internal audit in ensuring the effectiveness of enterprise risk management is described in details. Then, the $5 \mathrm{~S}$ implementation, which is a technique developed in order to create a quality working order in organizations and to ensure the continuity of the activities, is mentioned in the risk management process of the enterprise. In this concept, the $5 \mathrm{~S}$ implementation is presented as an example within the scope of internal audit activities in a company.

Keywords: Internal Audit, Risk Management, Corporate Risk Management, 5S Implementation

\section{Kavramsal Olarak İç Denetim}

İç denetim, tarihsel gelişim süreci içerisinde kavramsal olarak farklı dönemler, farklı şekilde tanımlanmıştır. Literatür incelendiğinde zaman içinde iç denetim kavramından bahsederken, "muhasebe kayıtlarının kontrolü, uygunluk değerlendirmesi, süreçlerin incelenmesi, kontrollerin değerlendirilmesi, iç kontrol sistemi etkinliğinin raporlanması, risk

Başvuru/Submitted: 15.07.2019 Kabul/Accepted: 26.07.2019

Sorumlu yazar/Corresponding author: Serdan Öner/serdan@hotmail.co.uk

Atıf/Citation: Oner, S. ve Adiloglu, B. (2019). İşletmelerde kurumsal risk yönetimi ve iç denetime farklı bir bakış açısı: 5S uygulaması. Muhasebe Enstitüsü Dergisi - Journal of Accounting Institute, 61, 67-82. https://doi.org/10.26650/MED.2019592032 
yönetiminin değerlendirilmesi" aşamalarından geçerek son olarak kurumsal risk yönetimi temelli çalışan bir yapıya dönüştüğü görülmektedir (Gönen ve Çelik, 2005:41-42).

Kısa adı IIA olan The Institute of Internal Auditors (Uluslararası İç Denetçiler Enstitüsü)'a göre iç denetimin tanımlaması şu şekildedir: "İç denetim, bir kurumun faaliyetlerini geliştirmek ve onlara değer katmak amacını güden bağımsız ve objektif bir güvence ve danışmanlık faaliyetidir. İç denetim, kurumun risk yönetim, kontrol ve yönetişim süreçlerinin etkinliğini değerlendirmek ve geliştirmek için sistemli ve disiplinli bir yaklaşım getirerek kurumun amaçlarına ulaşmasına yardımc1 olur" (IIA, Glossary of Terms, 2009)

Günümüzde iç denetimden sadece işletmede birtakım şeyler olduktan sonra geriden gelip, tespitte bulunması değil, daha önceden öngörülerde bulunması, işletmenin karşılaşabileceği riskleri ve firsatları ortaya koyması beklenmektedir. Dolayısıyla burada iç denetimin ilgilenmesi gereken önemli unsurlar, kurumsallık, kontrol ve risk yönetimi şeklinde sayılabilir (Kurnaz ve Çetinoğlu, 2010:32-33).

İç denetime yönelik çağdaş uygulamalar, ABD'de 1941 yılında kurulan “İç Denetçiler Enstitüsü” (IIA-Institute of Internal Auditors) ile başlamıştır. Bu dönemde işletmelerdeki iç denetim faaliyetleri; finansal denetimlere ve finansal işlemlerin doğruluğunun değerlenmesi rolünü üstlenirken zaman içinde enstitü tarafından yapılan denetçi tanımlarının işletme faaliyetleri ve iç denetim mesleğince yürütülen faaliyetleri tam anlamıyla kapsamadığı kanısına varılmıştır. 1999 yılında IIA tarafından iç denetim tanımlaması yeniden yapılmış, bu tanıma göre iç denetim; "işletmelerin operasyonlarını geliştirerek katma değer yaratmak için oluşturulan bağımsız ve objektif bir danışmanlık ve denetim aktivitesidir. Aynı zamanda işletmelerin mevcut risk yönetimi, kontrol ve kurumsal yönetim fonksiyonlarını değerlendirerek, etkinliklerin artması için sistematik bir yaklaşım getirmeyi amaçlamaktadır".

\section{2. İç Denetim ve Kurumsal Risk Yönetimi İlişkisi}

Artan ve yoğun rekabet ortamı, işletmelerin kendilerini yeniden yapılandırma sürecine gitmesini hızlandırmış; bu kapsamda finansal, operasyonel, çevresel ve sosyal riskleri yönetme ihtiyacı doğmuştur. Dolayısıyla işletmelerde iç denetim ile ilgili birimlerin, yaptıkları faaliyetlerde "risk odaklı iç denetim" yapması ve şirketlerdeki iç kontrol sisteminin yapılanması için risk değerleme sürecine önem verilmesi giderek yaygınlık kazanmaktadır (Demirbaş, 2005:168-169). İşletmenin tamamına yayılarak daha stratejik bir yaklaşımı ve denetimi amaçlayan "Kurumsal Risk Yönetimi uygulamaları" için şirket yönetim desteğinin alınması, hedeflenen katma değerin elde edilmesi açısından "risk odaklı iç denetim" önem arz etmektedir (Doyrangöl, 2002:41).

İç denetim bunların haricinde bir işletmedeki risk yönetimi, iç kontrol ve kurumsal yönetim ile ilgili tarafsız ve objektif güvence sağlayarak, işletmede bir tür danışmanlık vazifesi yapmaktadır (Aysan, 2007:19). Böylece iç denetim, kurumsal risk yönetimi ile birlikte, işletmenin yönetim anlamında hesap verebilmesi; şirket içinde şeffaflığın, adilliğin ve sorumluluğun yerleşmesine katkı sağlamaktadır.

İşletmenin faaliyetlerine devam edebilmesi için, müşterisinin ihtiyaçlarının yanı sıra, kendi ihtiyaçlarına da cevap verebilecek iş süreçlerine sahip olması, bunların düzenli olarak güncellenmesi, gözden geçirip, denetlemesi ve kontrol etmesi gerekir. Bu aşamada, iç denetim desteğine gerek vardır. İç denetim, işletmenin süreçleri doğru işleyip işlemediği, risklerin ne derece etkin yönetildiği, işletmenin ne kadar verimli olduğu konularılyla ilgilenmektedir. Bunlarla ilgili faaliyetleri yürütürken, "proaktif bir yaklaşım" ile hareket eden iç denetim, hata ve kusurlar meydana gelmeden gerekli tespitleri yapmaktadır (Akçakanat, 2012:43-44).

Günümüzde birlikte hareket eden "kurumsal risk yönetimi ve iç denetim süreçlerinin temel ilişkisi ne yöndedir?" diye sorulduğunda öncelikle iç denetimin, kurumsal risk yönetimindeki temel rolüne değinmek gerekir. Şöyle ki, iç denetimin kurumsal risk yönetimi konusundaki temel görevi; "bir işletmede önemli iş risklerinin uygun olarak yönetilmesini ve iç kontrol sisteminin etkili biçimde işlev görmesini sağlamada yardımcı olmaktır”. İşletmenin kurumsal risk yönetimi faaliyetlerinin etkililiği hakkında tarafsız ve objektif güvence sağlayabilmektir (Emhan, 2009:218-219). 


\section{Kurumsal Risk Yönetimi ve 4 T Yaklaşımı}

Türkçe'ye "Enterprise Risk Management"dan çevrilmiş olsa da "Corporate Risk Management", "Integrated Risk Management" gibi ifadeler de kurumsal risk yönetimi için kullanılmaktadır. Kurumsal risk yönetimi, bir işletmenin sahip olması gereken işlevden çok bir yönetim yetkinliği olarak kabul edilir. Çünkü kurumsal risk yönetimi; performans, strateji ve yönetim olmak üzere üç yaklaşımın karması olan bir anlayış biçimidir. (Merna ve Al Thani, 2008:2-3)

Daha özet bir ifadeyle kurumsal risk yönetimi, “işletme adına önemli olan iş risklerinin yönetimi için, gerekli yetkinliklerin olgunluk seviyesini sürekli olarak daha iyiye götüren bir yapıyı” hedefleyen yaklaşımdır(Emhan, 2009:210). Bu yapının kurumda süregelen ve her noktasında iyileştirmelerin devam ettiği bir hale gelmesi kurumsal risk yönetiminin temel özelliklerinden biridir.

Kurumsal risk yönetiminde "tespit, tahlil, tedbir ve takip” olarak sıralanan süreç, "4T yaklaşımı” olarak ifade edilmektedir.

- Tespit: Risklerin belirlenebilmesi için öncelikle işletmenin çevresini iyi tanıması; faaliyet sürdüğü pazarın yapısını iyi bilmesi gerekmektedir. İşletmenin sahip olduğu tecrübe ve çevreden alınan bilgi dâhilinde "sistematik ve sistematik olmayan riskler" saptanmaya çalışılmaktadır. Riskler saptanırken, tehdit ve firsatlar da ortaya çıkmaktadır (Berk, 2003:125126). Riskleri tespit ederken şu soruların sorulması gerekir: "Ne, nerede, ne zaman olabilir?" "Neden ve nasıl olabilir?" “Bunların belirlenmesi için hangi teknikler kullanılabilir?” (Pehlivanlı, 2011:13).

- Tahlil: Bu aşamada işletmenin kendisi ve diğer bütün iştirakleri, tüm yönetim ekibinin katılımının sağlanmasıyla anketler, olasılık analizleri gibi çalışmalar yaparak risklerin neler olduğunu tahlil edip öncelik belirlemektedir (Kızılboğa, 2012:303). Risklerin belirlenmesi için "risk haritaları, risk göstergeleri, iç değerlendirme, geçmiş kayıp verileri, workshoplar, diş denetim ve mevzuat gereklilikleri, en iyi uygulamalar ve yasal yükümlülükler” gibi araçlar kullanılmaktadır. (Börekçi, 2004:9)

- Tedbir: 4T yaklaşımının tedbir aşamasında, var olan risk yönetiminin ne düzeyde olduğu saptanır ve yeni risklere karşı yeni stratejiler geliştirilir. Başka bir deyişle, en uygun çözüm seçilir ve uygulamaya konulur. Problem teşkil edecek risklerin, gerçekleşmeden belirlenip, ortadan kaldırılması, risk yönetiminin esasıdır ancak bu her zaman mümkün olmamaktadır. Bu durumda "Belirlenen risklerin meydana gelme olasılığı ve etkisinin en aza indirgemesini sağlayan faaliyetler planlanıp uygulanmaktadır" (Arslan, 2008:43).

-Takip: Diğer adı “performans ölçümü” olan bu aşamada, kabul edilebilir düzeydeki risklerin takibi yapılmaktadır. Eğer izlenen riskin ölçümlenme olanağı var ise, bu risk, "sayılabilen risk" şeklinde adlandırılmaktadır (Bolgün ve Akçay, 2003:120).

Kurumsal risk yönetimindeki bütün aşamalar, birbirini takip etmez, çünkü risk yönetimi sürekli takip edilerek geliştirilen bir süreçtir ve bu süreçte değerler zaman içinde birbirini besleyerek gelişmeye devam eder (Pehlivanlı, 2011:17).

İç Denetçiler Enstitüsü'nün üzerinde durduğu nokta, risk yönetimindeki sorumluluğun işletme yönetimine ait olduğu konusunun tüm kurumlar tarafından benimsenmiş olmasıdır. (Güneş ve Teker, 2010:69). Dolayısıyla iç denetim ve risk yönetimi ilişkisi değerlendirilirken iç denetçilerin görevleri dâhilinde bilinmesi gereken birtakım hususlar vardır. Çünkü bir iç denetçi sadece risk yönetimi kararını vermekle kalmayıp risk konusunda tepe yönetime tavsiyede bulunur, yönetimin aldığı kararları sorgular veya destekler (Saka ve Uğural, 2009:13). Dolayısıyla kurumsal risk yönetimi ile ilgili olarak iç denetçilerin sorumluluklarında üzerinde durulması gereken etmenleri, aşağıdaki şekilde sıralamak mümkündür (Yörüker, 2004: 9-11):

- Tepe yönetim, risk yönetimi konusunda sorumlu taraf olduğunu kabul etmeli ve bu geçerliliğini korumalıdır.

- İç denetimin sorumluluklarının çerçevesi, denetim komitesi tarafından onaylanarak denetim tüzüğü içinde yer verilip belgeye dayandirılmalıdır.

- İç denetimin, işletme yönetimi yerine herhangi bir riski kendi başına yönetme yetkisi yoktur. 
- İç denetim, risk yönetimi ile ilgili tek başına almaktan kaçınmalı; yönetimin kararına göre öneri ve yapısı eleştiride bulunmalıdır.

- İç denetim, kurumsal risk yönetimi dâhilinde aynı zamanda tarafsız güvence veremez. Bu gibi konularla ilgili güvenceler, uygun niteliklere sahip diğer taraflardan sağlanmalıdır.

- Güvence faaliyetlerinin haricindeki çalışmalar, danışmanlık hizmeti şeklinde görülmeli ve danışmanlık hizmetleriyle alakalı iç denetim uygulama standartlarına uyum sağlanmalıdır.

Sonuç olarak iç denetim ve kurumsal risk yönetim süreçlerinin ilişkisini değerlendirdiğimizde her ikisinin de bir işletmeye kattıkları değer şu şekilde özetlenebilir:

- Önemli iş risklerinin doğru ve etkin biçimde yönetildiğine dair "tarafsız güvence"

- Kurumsal risk yönetimi ile iç kontrol yapılarının etkin biçimde işlemesi konusunda danışmanlık sağlamaktır.

\section{Kurumsal Risk Yönetimi ve İç Denetim İlişkisine Yeni Bir Bakış Açısı: 5S Uygulaması}

İç denetimin temel görevlerinden birisi, risk yönetim süreçlerinin tam, etkin ve verimli olduğu konusunda üst yönetime ve yönetim kuruluna objektif güvence sağlamaktır. Kendisine risk değerlendirmesini temel alan iç denetim faaliyetleri, "kurumsal yönetim, risk yönetimi ve iç kontrol süreçlerinin işletmenin karşılaştığı risklerin belirlenmesi, tanımlanması ve bu risklerle mücadele konularında yeterliliğinin ve etkinliğinin belirlenmesini kapsamaktadır.” Dolayısıyla iç denetimin temel görevlerinden birisi, risk yönetim süreçlerinin tam, etkin ve verimli olduğu konusunda üst yönetime ve yönetim kuruluna objektif güvence sağlamaktır.

Çalışmanın bu bölümünde iç denetim faaliyetleri ile ilgili farklı bir uygulama biçimi ele alınmıştır. 5S adı verilen bu uygulama Japonlar tarafından geliştirilen ve işletmedeki en kü̧̈ük detayların bile denetlenmesine firsat veren önemli kurallar bütünüdür. 5S, organizasyon içerisinde kaliteli bir çevre kurmak ve bunu korumak için kullanılan bir tekniktir. Çalışma alanını temiz, düzenli ve amaca uygun biçime sokulması için uygulanan bir toplam kalite tekniğidir. Aynı zamanda, işletmelerdeki düzen ve disiplini sağlamak için kullanılan hem basit, hem de işletmenin en küçük ayrıntılarının denetimini sağlayan ve diğer iyileştirme çalışmalarının temelini oluşturan bir sistemdir.

(https://yalindanisman.com/yalin-yazarlar-5s-uygulama-yaklasimi-ve-tarihi/)

$5 \mathrm{~S}$ uygulaması işyerlerindedüzeninin sağlanmasının, gereksiz malzeme stokunun engellenmesinin, çalışan verimliliğinin arttırılmasının, düzgün ve kolay ulaşılır arşivleme yapılmasının, malzeme ve işgücü israfının azaltılmasının sağlanması amacıyla bir araya getirilip uygulanması ile oluşturulan bir sistematiktir.(Tekin vd, 2018: 113) Bu kapsamda bir işletmede üretim, hammadde depo, mamul depo, teknik ve tüm çalışma ofislerinin fabrika içerisinde iç denetim faaliyetleri kapsamında $5 \mathrm{~S}$ çalışması örnek olarak aşağıda sunulmuştur. Çalışma öncesi tespitler öncelikle belirtilmiş ardından 5S uygulaması ile birlikte bulgular ve iyileştirme önerileri sunulmuştur.

\subsection{S Tanımı}

Orijinali Japonca olan 5S kuralı şu şekilde özetle sınıflandırılmaktadır; (Osada,1991:10-15)

\section{1) Seiri (Toparlama/Ayıklama)}

İş ortamını daha iyi organize etmek için gerekli ile gereksiz olan malzemeleri doğru şekilde ayırt etme ve birbirinden uzaklaştırma işlemidir.

\section{2) Seiton (Stralama Veya Düzenleme)}

Gerekli olan malzemeleri kolayca bulmak, kullanmak ve yerine koymak için yapılan düzenlemelerdir.

\section{3) Seiso (Temizleme)}

İş ortamındaki her şeyi temiz tutma işidir. 


\section{4) Seiketsu (Standartlaştırma)}

Ayıklama, düzenleme ve temizleme adımları ile elde edilenlerin sürekliliğini sağlamak için yapılan işlemlerdir. Standartlaştırma, gelinen noktadan geriye doğru dönüşün bir sistem oluşturularak engellenmesidir.

\section{5) Shitsuke (Disiplin, Sahiplenme ve Sistemi Koruma)}

Sürekliliğin sağlanması için kalıcı bir alışkanlık yaratılarak çalışma ortamında kültürel değişimin sağlanmasıdır. Elde edilecek disiplin ile belirlenen prosedürlere uyumun devamlılığı sağlanır.

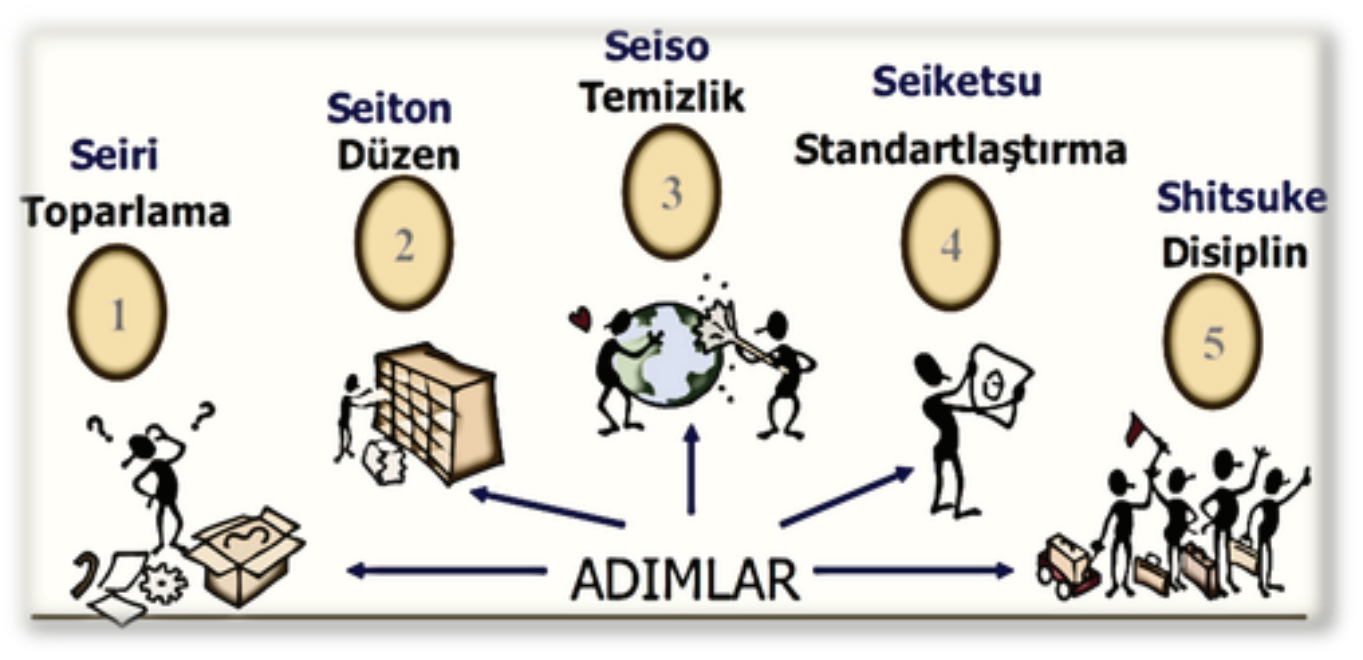

Şekil 1. 5S Süreci

Kaynak: https://kalitece.wordpress.com/2017/06/22/

kalite-gelistirme- tekniklerinin-ilk-basamagi-5s-yontemi-ve-uygulamalari/

Bir iş yeri organizasyonu olarak adlandırılan 5S'in amacı iş yerindeki malzeme ve bilgi akışının hızlı ve doğru olmasını sağlamaktadır. Bu amaca ek olarak aşağıdakiler sıralanabilir:

- Çalışanların saygı ve güven duyduğu,

- İşi kolaylaştıran,

- Verimliliği arttıran,

- Kalite ürün/hizmet sağlamaya destek olan,

- İş güvenliliğini arttıran,

- Müşteri memnuniyetini arttıran,

- Temiz ve düzenli bir iş yeri oluşturmaktır.

5S'in faydaları ise şu şekilde belirtilebilir. (Osada,1991)
SIFIR İSRAF:
Daha Düşük Maliyet, Daha Yüksek Kapasite
SIFIR ARIZA:
Daha İyi Bakım, Daha Az Arıza
SIFIR HURDA:
Daha Yüksek Kalite
SIFIR GECIKME:
Daha Az Bekleme, Güvenilir Teslimat
SIFIR ŞIKAYET:
Daha Az Şikayet, Daha Fazla Güven
SIFIR KAZA:
Daha Güvenli İş Ortamı
YÜKSEK IMMAJ:
Sürekli Büyüyen Bir Kuruluş 


\subsection{S Uygulaması Öncesi Yapılan Tespitler}

İç denetçi, X firmasına yeni işine başladıktan sonra 2 hafta boyunca tüm departmanlar ile oryantasyon yapmıştır. Bu oryantasyon sürecinde bazı gözlemleri olmuştur. Çalışma ofisleri, üretim sahası, hammadde depo ve mamul depo saha çalışmalarında aldığı gözlemler ve tespitler aşağıdaki gibidir.

1) Düzenli ve temiz bir çalışma ortamı bulunmamaktadır.

2) İşe giriş çıkışlarda uyulmama vardır.

3) Çalışma masalarında kahvaltı edilmektedir.

4) Paletlerin, transpaletlerin vb günlük kullanılan malzeme ve/veya araçların düzensizlik bir şekilde muhafaza edilmektedir.

5) Çalışan memnuniyetsizliği ve şikayeti çok fazla sayıdadır.

6) Sevkiyatlar zamanında yapılmamaktadır.

7) Ürün hataları ve müşteri şikayetleri çok fazla sayıdadır.

8) İş güvenliği kuralları uygulanmamaktadır ve geçmişte fazla sayıda iş kazası kaydı bulunmaktadır.

9) Depo içerisinde uyarıcı ve yönlendirici levhalar bulunmamaktadır.

10) Ürün satın alınmasında gecikmeler olduğu için satışın zamanında yapılmaması durumları vardır.

11) Makinelerin ve cihazların arıza bakımı sıklıkla olmaktadır.

12) Depo girişlerinde tanımlar bulunmamaktadır.

13) Depo raflarında adres lokasyonları belirtilmemiştir, etiketlendirme yoktur.

14) Teknik ofiste kullanılan tamir aletleri düzensiz bir şekilde muhafaza edilmektedir.

15) Gereksiz ekipman, hammadde, yarı mamul ve mamul taşımaları yapılmaktadır.

16) İyi organize edilmemiş iş ortamı nedeniyle oluşan gereksiz iş hareketleri, malzeme aramaları vb yapılmaktadır.

Denetçi, bu gözlemler sonrası 5S uygulaması konusunda yönetimi bilgilendirmiş ve $5 \mathrm{~S}$ uygulamasına geçilmesi yönetim tarafından onaylanmıştır.

\subsection{S Kurulu, 5S Ekip Lideri ve 5S Ekibinin Seçilmesi}

İşletmede öncelikle $5 S^{\prime}$ in ne olduğu, ne işe yaradığ 1 ve beklenen faydalar ile ilgili bir eğitim verilmiş, sonrasında İç denetim departmanın 5S Proje Lideri olması öncülüğünde 5S Kurulu, 5S Liderleri ve 5S Ekibi seçilmiştir, görev tanımları belirlenmiştir.

\subsubsection{S Kurulu}

5S ekiplerinin oluşturulmasını sağlamak. (Eğitime katılan personel Departman/Ekip Lideri olur ve o uygun sayıda departman/ekip temsilcilerini seçer).

- $5 \mathrm{~S}$ uygulama alanların belirlemek ve tanımlamak.

- 5S uygulamaları için gerekli kaynakları temin etmek.

- $5 \mathrm{~S}$ ekiplerini yönlendirmek ve desteklemek.

- Gereksiz malzemeler için nihai kararı vermek.

- 5 S ekiplerinin uygulamalarını denetlemek, değerlendirmek ve gerektiğinde ödüllendirmek.

- $5 \mathrm{~S}$ uygulamalarının sürekliliğini sağlamak.

- 5S disiplini oluşturmak.

- 5S Performans sonuçları hakkında üst yönetimi bilgilendirmek.

\subsubsection{S Ekip Lideri}

- 5S Ekibine liderlik etmek.

- 5S uygulamalarının sürekliliğini sağlamak ve departman personeline gerekli

- bilinçlendirme eğitimleri vermek.

- 5S adımlarında yapılacak faaliyetleri organize etmek. 
- Gereksiz malzemelerin tespiti, kırmızı etiketlenmesi ${ }^{1}$ ve Kırmızı Etiket takip listelerinin hazırlanmasını sağlar. Gerek Kırmızı Etiket takip listelerinin gerekse üzerinde kararsız kalınan objeleri ve bunlar için verilecek nihai karar onayını 5S kuruluna sunmak.

- $\quad 5 S$ panolarının güncelliğini takip etmek.

- 5S ekip toplantılarını gerçekleştirmek ve sonuçları kayıt altına almak.

\subsubsection{S Ekibi}

- $5 \mathrm{~S}$ adımlarında yapılacak faaliyetler ve hedefler ile ilgili karar almak

- $5 \mathrm{~S}$ adımlarında takip edilecek hedefleri, yapılacak faaliyetleri ve sorumlulukları belirlemek.

- Toplantılar sonucunda alınan kararlar ve belirlenen sorumluluklar doğrultusunda uygulamaları gerçekleştirmek.

- $\quad$ SS ekip liderine destek olmak.

\subsection{S Uygulama Alanlarının Belirlenmesi}

5S, X firmasının tüm alanlarında uygulanmıştır. 5S Kurulu tarafından fabrika alanı bölgelere ayrılmış ve 5S uygulanacak alanların sırası 5S Kurulu tarafından belirlenmiştir. Belirlenen alanlara 5S panosu ve "5S uygulama alanı" flamaları asılarak 5S faaliyeti başlatılmıştır.

\subsection{S Panolarının Kullanımı}

5S panoları her uygulama alanı için standarttır. Bu panolar 5S ekipleri tarafından aşağıdaki şekilde kullanılır ve güncelliği 5S ekip lideri tarafından sağlanır. Panolarda aşağıdaki bilgiler yer alır.

- $5 \mathrm{~S}$ ekip üyeleri (ekip lideri belirtilir) listesi,

- 5S slogan1,

- $\quad 5 \mathrm{~S}$ kırmızı etiket takip listesi,

- Temizlik sorumluluk haritası

- Temizlik takvimi

- Temizlik malzeme listesi

- Temizlik talimatı

- Önceki durumu ve uygulamalar sonrasındaki durumu karşılaştıran fotoğraflar

- $\quad$ Ekip toplantı tutanakları.

\subsection{Temizlik Takvimi Formu, Günlük ve Haftalık Kontrol Listesi Oluşturulması}

5S Kurulu tarafından iç kontrol sisteminin etkin bir şekilde yürütülmesini ve 5S kavramının şirket çalışanları tarafından içselleştirilmesini sağlamak amacıyla “Temizlik Takvimi Formu” ve “Günlük Ve Haftalık Kontrol Listesi”” oluşturulmuştur.

\section{Tablo 1: Örnek 5S Temizlik Takvimi}

\begin{tabular}{|c|c|c|c|c|c|}
\hline \multicolumn{6}{|c|}{ 5S Temizlik Takvimi } \\
\hline \multicolumn{6}{|c|}{ Bölge: Dinlenme Odası } \\
\hline Gün & $\begin{array}{c}\text { Kahve } \\
\text { Makinası }\end{array}$ & Yerler & Masalar & Küllükler & Lavabo \\
\hline P.tesi & Ali & Ali & & Veli & \\
\hline Salı & Veli & & Veli & Hilmi & Nuri \\
\hline Çarşamba & Hilmi & & & Nuri & \\
\hline Perşembe & Nuri & & & Niyazi & \\
\hline Cuma & Niyazi & & Niyazi & Ali & Hilmi \\
\hline
\end{tabular}

1 Ayıklama adımında" kırmızı etiket” tekniği, alandaki gerekli ve gereksiz olanları birbirinden ayırt etmek ve gereksiz malzeme ve/veya işlem adımlarını kayıt altına almak için ilgili unsurların üzerlerine kırmızı etiketler yapıştırmak sureti ile kullanılır. 


\subsubsection{S Günlük ve Haftalık Kontrol Listeleri}

Aşağıda verilen ayıklama, düzenleme ve temizlik aşamaları için kontrol listeleri örneği verilmiştir.Her 5S Ekibinin veya Ekip Liderinin kendi sahasına özgün kontrol listelerini ayıklama, düzenleme ve temizlik aşamaları için aşağıdaki örneğe benzer şekilde hazırlaması önerilmiştir. Ayrıca her 5S Bölgesinin ilgili amirinin (5S Ekibinin dışında olan Müdür/ Şef / Sorumlu) kendi sahasına özgün kontrol listelerini ayıklama, düzenleme ve temizlik aşamaları için aşağıdaki örneğe benzer şekilde hazırlaması veya 5S Ekibinin Kontrol listesi üzerinde uzlaşarak ortak kullanılabilir.

1. Ayıklama Kontrol Listesi (örnek)

a) Stok alanında kullanılmayan nesneler var mi?

b) Koridorlarda kullanılmayan herhangi bir şey var mı?

c) İhtiyaç duyulmayan herhangi bir makine var mı?

d) Rafların üstünde veya altında gereksiz herhangi bir şey var mı?

e) Makinelerin çevresinde veya altında gereksiz herhangi bir şey var mı?

f) Gereksiz malzemeleri fabrikaya bir bakışta ayırt edebiliyor musunuz?

g) Aletlerin sayısını azaltmak için tüm olası iyileştirmeler yapıldı mı?

2. Düzenleme Kontrol Listesi (örnek)

a) Ürünlerin stokları tamamen düzenli mi?

b) Stoklara bir bakışta miktar göstergeleri bulunabilir mi?

c) Nesneleri birbirinden ayırmak için paravanlar kullanılıyor mu?

d) Stok alanları tanımlı mi?

e) Bütün stok alanları, nesnelerin eğilerek alınmasını gerektirmeyecek şekilde yeterince yüksekte mi?

f) Tepeleme yı̆̆ılmış nesnelerin çökmeyeceği kesin mi?

g) Tepeleme yığılmış nesnelerin yüksekliği makul seviyede mi?

h) Aletler için açık depolama sistemi var mı?

i) Aletler düzenli mi?

j) Aletlere isimleri ve kod numaraları yapıştırılmış mı?

k) Düzenli olarak kullanılan aletler çalışma alanının yakınında mı?

1) Aletler uygun koruyucular içinde mi?

m) Seyrek kullanılan aletler ortak kullanıma uygun yerde mi?

n) Çekmecedeki araçlar önden arkaya doğru düzenlenmiş mi?

o) Depolanan nesnelerin hepsi bir bakışta görülüyor mu?

p) Nesneler mükemmel bir şekilde depolanıyor mu?(Yatay, düşey, doğru açılarda, paralel.)

q) Alanın en uygun şekilde kullanılması için depolama 3 boyutlu mu?

r) Doğrudan yere konarak depolanan nesne kalmamış mı?

s) Hurda parçaların depolanması tanımlı mı?

t) Hurda parçaların depo alanları açıkça etiketlenmiş mi?

u) Depolama iş planına göre yapılıyor mu?

v) Yanlış yerlere konan nesneleri belirtmek kolay mı?

w) Düzensiz depolamalar hemen düzeltiliyor mu?

x) Yer çizgilerinin \%80’ i çizildi mi?

y) Hurda parçalar bir bakışta görülebiliyor mu?

z) Nesnelerin ne kadar kolay geri konulduğuna dikkat ediliyor mu?

aa) Düzenli kullanılan nesneler kullanım yerinin $10 \mathrm{~cm}$ içinde bulunuyor mu?

ab) Tüm tehlikeli alanların etrafı çevrelenmiş mi?

ac) Tüm tehlike ikazları açık ve kolayca görünür vaziyette mi? 


\section{Temizleme Kontrol Listesi (örnek)}

a) Makine ve ekipmanların altındaki tüm su, yağ ve kir temizlendi mi?

b) Makine ve ekipmanların üstündeki tüm pas, kir ve yağ lekesi temizlendi mi?

c) Makine, ekipman ve kontrol panellerinin üstündeki yağlı ve kirli parmak izleri temizlendi mi?

d) Makinelerin yağ göstergeleri ve ölçüm aletlerinin göstergeleri üzerindeki kirler temizlendi mi?

e) Makinelerin tüm kapakları, içerideki kir ve tozun görülebilmesi için kaldırıldı mı?

f) Aletler üzerindeki kir ve toz temizlendi mi?

g) Ürün ambarındaki dolaplar ve raflar tozdan arındırılmış mı?

h) Malzeme taşıma için kullanılan transfer paletlerindeki tüm kir temizlendi mi?

i) Ürün, malzeme ve yarı mamuller tozdan arındırılmış mı?

j) Tüm duvar, pencere ve pervazlardaki toz ve kir temizlendi mi?

k) Pencerelerdeki tüm kirli parmak izleri temizlendi mi?

1) Tavanlardaki ve asma katlardaki tüm toz ve kir temizlendi mi?

m) Tüm raflar ve çalışma masaları üstündeki kir ve toz temizlendi mi?

n) Merdiven ve basamaklar üzerindeki tüm yağ ve kir temizlendi mi?

o) Tüm köşe, duvar ve sütunların dibindeki kir ve pislik temizlendi mi?

p) Binaların etrafındaki genel kirlilik temizlendi mi?

q) Dış duvarların dış yüzeyleri temizlendi mi?

r) Tüm koridor ve yerler parliyor mu?

s) Yerlerdeki ve koridorlardaki tüm kum, toprak, toz, kir temizlendi mi?

\subsection{Risk Değerlendirmesi}

Kontrol listelerinin oluşturulmasından sonra alınan cevaplar sonrası risk değerlendirme adımına geçilmiş ve kurumsal risk matrisleri oluşturulmuştur. İç kontrol ve iç denetim risk değerlendirmesi; şirketin faaliyet alanlarına ilişkin risk faktörlerinin tanımlanmasını, risk seviyelerinin ölçülmesini, bu riskler için uygulanan kontrollerin etkinlik ve yeterliliğinin değerlendirilmesini ve yüksek risk içeren alanlara denetim önceliğinin verilmesini öngören bir denetim yaklaşımıdır.

$\mathrm{X}$ işletmesinde riskin niteliksel değerlendirilmesinde Risk Değerlendirme Tablosu (RDT) yönteminden faydalanılmıştır. RDT, risklerin değerlendirilmesinde, değerlendirme sonuçlarına göre hangi işlere öncelik verilmesi ve kaynakların öncelikle nereye aktarılması konularında kullanılan bir tekniktir. Bu tablonun hazırlanması, sistemin risklerinin tahmini için geçmişteki olaylardan kazanılan deneyimlere başvurma anlayışına dayanmaktadır.

- Yatay eksen; Etki seviyelerini (0-5) ifade eder.

- Dikey eksen; sonuçla ilgili artan Olasılı̆̆ı temsil eder.

- Tablodaki kutular; tablonun sol üst köşesinden sağ alt köşesine doğru artan Risk Seviyelerini tanımlamaktadır.

- Riskin seviyesini tanımlamak için tablo Kırmızı, Mavi ve Yeşil alanlara ayrılmıştır.

Riskleri değerlendirirken tehlikenin neden olduğu olayın şiddeti ve olasılığı dikkate alınmıştır. Belirlenen riskler için 5x5 Risk Değerlendirme Tablosu kullanılmıştır. Burada risk, Risk= Olasılık x Etki formülüyle hesaplanmaktadır. Formüldeki olasılık ve şiddet değerleri için aşağıdaki tablolarda verilen değerler kullanılmıştır. 


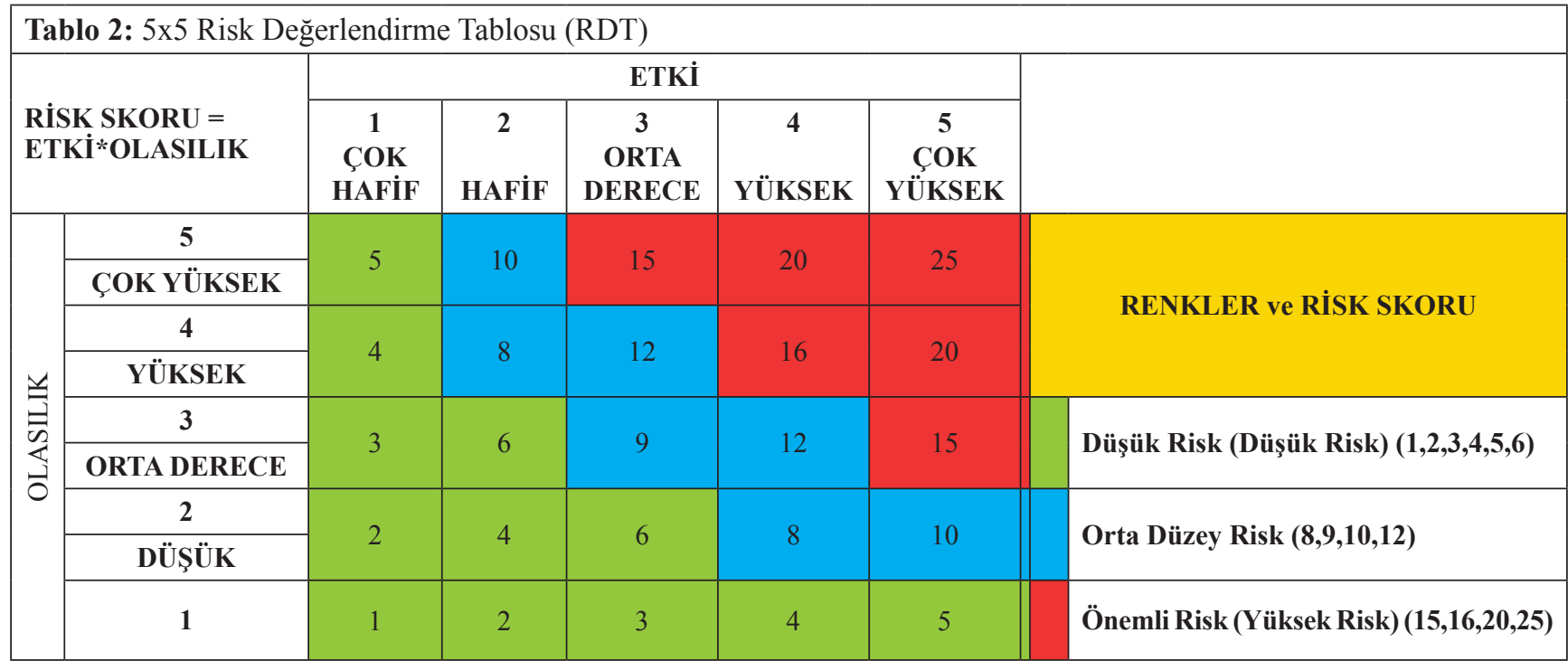

\subsection{Aylık Denetim Formunun Oluşturulması}

Risk değerlendirme tablosundan elde edilen sonuçlar doğrultusunda işletmenin risk haritası çıkarılmış ve denetimde öncelik sıraları belirlenmiştir. Özellikle risk haritasındaki kırmızı bölgelerle ilgili iyileştirme çalışmalarının bir an önce başlatılması ve olması gereken adımlarla faaliyetlerin devamlılığının sağlanması hedeflenmiştir. Bu doğrultuda İç Denetim Müdürü tarafından tüm işletme genelini kapsayan "aylık denetim formları” oluşturulmuştur. 
5S DENETLEME FORMU

Denetlenen alan:

İlgili Kişi:

Denetleyen:

Tarih:

\begin{tabular}{|c|c|c|c|c|}
\hline & $\begin{array}{c}\text { Soru } \\
\text { No }\end{array}$ & Beklentiler / Sorular & Puan & Önlemler \\
\hline \multirow{5}{*}{ 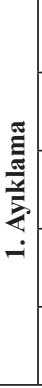 } & 1 & $\begin{array}{l}\text { Çalışma alanında gerekli olmayan makine, yardımcı alet, } \\
\text { ekipman, ölçüm aleti, aparat, mastar, anahtar vb. yok. }\end{array}$ & & \\
\hline & 2 & $\begin{array}{l}\text { Çalışma alanında gerekli olmayan dolap, masa, sandelye, } \\
\text { çekmece, kova, temizlik malzemeleri vb. malzemeler yok. }\end{array}$ & & \\
\hline & 3 & $\begin{array}{l}\text { Çalışma alanında gerekli olmayan hammadde, yarı mamül, } \\
\text { ambalaj malzemesi veya ürüne katılacak vb. malzemeler yok. }\end{array}$ & & \\
\hline & 4 & $\begin{array}{l}\text { Çalışma alanında gerekli olmayan bilgi ve dokümanlar (dosyalar, } \\
\text { prosedürler, teknik resimler, poster, formlar vb) yok. }\end{array}$ & & \\
\hline & 5 & $\begin{array}{l}\text { Değerlendirilmesi tamamlanan kırmızı kartlı ürünler çalışma } \\
\text { alanından uzaklaştırılmıştır. }\end{array}$ & & \\
\hline \multirow{11}{*}{ 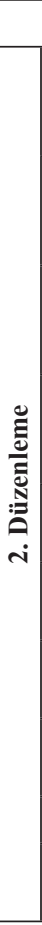 } & & Ayıklama Aşaması Puanı & $\mathbf{0}$ & \\
\hline & 1 & $\begin{array}{l}\text { Çalışma alanında kulanılan makine, yardımcı alet, ekipman, } \\
\text { ölçüm aleti, aparat, mastar, anahtar vb. düzenli, gerekli olan } \\
\text { yerde, yer çizgileri veya alan tanımlamaları var. }\end{array}$ & & \\
\hline & 2 & $\begin{array}{l}\text { Çalışma alanında kullanılan dolaplar, raflar, masalar, çekmeceler } \\
\text { düzenli, gerekli olan yerlerde tanıtım etiketleri, yer çizgileri veya } \\
\text { alan tanımlamaları var. }\end{array}$ & & \\
\hline & 3 & $\begin{array}{l}\text { Çalışma alanında kullanılan kova, paspas, süpürge, faraş ve } \\
\text { temizlik malzemeleri düzenli, gerekli olan yerlerde, yer çizgileri } \\
\text { veya alan tanımlamaları var. }\end{array}$ & & \\
\hline & 4 & $\begin{array}{l}\text { Çalışma alanında kullanılan hammadde, yarı mamül, ambalaj } \\
\text { malzemesi veya ürüne katılacak vb. malzemeler düzenli, etiketli } \\
\text { veya tanımlı. gerekli olan yerlerde, kritik stok seviyeleri var. }\end{array}$ & & \\
\hline & 5 & $\begin{array}{l}\text { Çalışma alanında düzeni bozan kişisel eşyalar (giyecek, yiyecek, } \\
\text { içecek, cep telefonu, çakmak, sigara vb) yok. }\end{array}$ & & \\
\hline & 6 & $\begin{array}{l}\text { Düzenleme aşamasında işin kolay yapılmass, ekipmanların } \\
\text { kullanım sıklı̆̆ı, kolaylığı ve verimlilik dikkate alınmış. }\end{array}$ & & \\
\hline & 7 & $\begin{array}{l}\text { Düzenleme aşamasında yenilikçi yaklaşım (inovasyon) } \\
\text { uygulanmış. }\end{array}$ & & \\
\hline & 8 & $\begin{array}{l}\text { Düzenleme uygulamaları arananın bulunmasını kolaylaştırıyor, } \\
\text { 30sn kuralı işliyor. }\end{array}$ & & \\
\hline & 9 & Gerekli malzeme listesi oluşturulmuş ve güncel. & & \\
\hline & 10 & $\begin{array}{l}\text { Yürüme yolları ve stok alanlarını açıkça belirlemek için çizgiler } \\
\text { veya diğer işaretler kullanılmış mı? }\end{array}$ & & \\
\hline \multirow{11}{*}{ 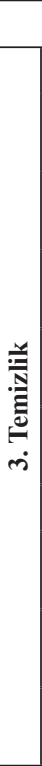 } & & Düzenleme Aşaması Puanı & $\mathbf{0}$ & \\
\hline & 1 & Yerler, duvarlar ve camlar temiz. & & \\
\hline & 2 & $\begin{array}{l}\text { Çalışma alanında kulanılan makine, yardımcı alet, ekipman, } \\
\text { ölçüm aleti, aparat, mastar, anahtar vb. temiz. }\end{array}$ & & \\
\hline & 3 & $\begin{array}{l}\text { Çalışma alanında kullanılan dolaplar, raflar, masalar, çekmeceler } \\
\text { temiz. }\end{array}$ & & \\
\hline & 4 & $\begin{array}{l}\text { Çalışma alanında kullanılan kova, paspas, süpürge, faraş ve diğer } \\
\text { temizlik malzemeleri temiz. }\end{array}$ & & \\
\hline & 5 & $\begin{array}{l}\text { Çalışma alanında kullanılan hammadde, yarı mamul, ambalaj } \\
\text { malzemesi veya ürüne katılacak vb malzemeler temiz. }\end{array}$ & & \\
\hline & 6 & $\begin{array}{l}\text { Kirlilik kaynakları biliniyor? Gerektĭginde önlem almak için } \\
\text { harekete geçilmiş. }\end{array}$ & & \\
\hline & 7 & Temizlik takvimi ve temizlik sorumlulukları belli. & & \\
\hline & 8 & $\begin{array}{l}\text { Operatörler makinanın veya Beyaz yakalılar ofis, masa ve dolap } \\
\text { kontrolünü yaparken aynı zamanda temizliyorlar mı? }\end{array}$ & & \\
\hline & 9 & $\begin{array}{l}\text { Operatörler söylenmeden yerleri süpürüyor ve makinelerini } \\
\text { temizliyorlar mı? (Beyaz yakalıların ofis temizliği hariçtir) }\end{array}$ & & \\
\hline & 10 & $\begin{array}{l}\text { Ortamdaki yoğun toz ve kokuyu temizlemek için yeterli bir } \\
\text { havalandırma var mı? }\end{array}$ & & \\
\hline & & Temizlik Aşaması Puanı & & \\
\hline
\end{tabular}




\begin{tabular}{|c|c|c|c|c|c|c|}
\hline \multirow{9}{*}{ 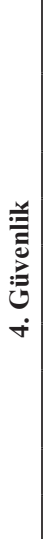 } & 1 & $\begin{array}{l}\text { Çalışma alanında düşme, elektrik çarpması, kesilme, sıkışma, } \\
\text { ezilme vb. riskler kabul edilebilir düzeyde. }\end{array}$ & & & & \\
\hline & 2 & $\begin{array}{l}\text { Çalışma alanında bel, sırt, boyun incinmesi ve meslek hastalığı } \\
\text { riskleri kabul edilebilir düzeyde. }\end{array}$ & & & & \\
\hline & 3 & Düzenleme aşamasında iş güvenliği dikkate alınmış. & & & & \\
\hline & 4 & Uyarı işaretleri var. & & & & \\
\hline & 5 & $\begin{array}{l}\text { Kişisel koruyucu ekipmanlar (maske, kulaklık, eldiven vs.) } \\
\text { kullanılıyor. }\end{array}$ & & & & \\
\hline & 6 & Aydınlatmanın açısı ve şiddeti yapılan iş için yeterli. & & & & \\
\hline & 7 & $\begin{array}{l}\text { Yangın dolaplarının ve tüplerinin yerleri tanımlı, önü açık ve } \\
\text { kolayca erişilebiliyor. }\end{array}$ & & & & \\
\hline & 8 & Tüm yangın söndürücü işaretleri her yerden görünebiliyor. & & & & \\
\hline & 9 & Tüm yangın söndürücüler uygun şekilde stoklanmış. & & & & \\
\hline \multirow{6}{*}{ 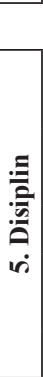 } & \multicolumn{6}{|c|}{ Güvenlik Aşaması Puanı } \\
\hline & 1 & $\begin{array}{l}\text { Çalışanlar mola ve toplantı zamanları konusunda kurallara } \\
\text { uyuyorlar. }\end{array}$ & & & & \\
\hline & 2 & $\begin{array}{l}\text { Çalışanlar biraraya gelip kuralları ve düzenlemeleri gözden } \\
\text { geçiriyorlar. }\end{array}$ & & & & \\
\hline & 3 & Çalışanlar kurallara ve düzenlemelere uyuyorlar. & & & & \\
\hline & 4 & $\begin{array}{l}\text { Çalışanlar işletme tarafindan belirlenen kılık kıyafet kurallarına } \\
\text { uyuyorlar. }\end{array}$ & & & & \\
\hline & 5 & İlk 3S alışkanlık haline gelmiş. & & & & \\
\hline \multicolumn{7}{|c|}{ Disiplin Aşaması Puanı } \\
\hline \multirow{3}{*}{ 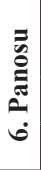 } & 1 & $\begin{array}{l}\text { Panoda, 5S+1 sloganı, ekip üyeleri, ekip lideri, tanıtım kartı vb } \\
\text { var (prosedürde belirtilen). }\end{array}$ & & & & \\
\hline & 2 & Pano, 5S+1 kurulunun belirlediği düzende kullanılıyor. & & & & \\
\hline & 3 & Önceki ve sonraki durumu gösteren fotoğraflar var. & & & & \\
\hline \multirow{8}{*}{ 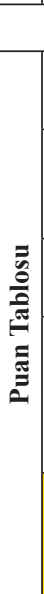 } & & 5S+1 Panosu Kullanım Puanı & & & & \\
\hline & & Toplam soru adedi & 44 & \multirow{7}{*}{ 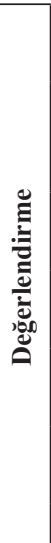 } & $\begin{array}{l}\text { Bu soru bu bölgede geçerli } \\
\text { değil veya denetlenemedi }\end{array}$ & GD \\
\hline & & Geçersiz soru adedi & & & $\begin{array}{l}\text { Tamamı, diğer gruplara örnek } \\
\text { olacak şekilde uygulanmakta } \\
(\% 100)\end{array}$ & 5 \\
\hline & & Maximum puan & 220 & & $\begin{array}{l}\text { Büyük çoğunluğu, beklentileri } \\
\text { karşılamakta }(>\% 80)\end{array}$ & 4 \\
\hline & & Alunan Puan & 0 & & $\begin{array}{l}\text { Beklentilerin yarısından fazlası } \\
\text { karşılanmakta }(>\% 50)\end{array}$ & 3 \\
\hline & & & & & $\begin{array}{l}\text { Beklentilerin yarısından azı } \\
\text { karşıllanmakta }(<\% 50)\end{array}$ & 2 \\
\hline & \multirow{2}{*}{\multicolumn{2}{|c|}{ GRUP BAŞARI PUANI }} & \multirow[t]{2}{*}{$\mathbf{0 , 0 0}$} & & $\begin{array}{l}\text { Beklentilerin çok azı } \\
\text { karşılanmakta }(<\% 20)\end{array}$ & 1 \\
\hline & & & & & Uygulama yok & 0 \\
\hline
\end{tabular}

\subsection{Yapılan Tespitler}

Yapılan iç kontrol çalışması neticesinde aşă̆ıda çok önemli tespitler yapılmıştır.

1) Son ürünler için kullanılan ambalaj ve etiketlerin ayıklanarak stokların depolanmadığı ve mevcut durum kayıtlarla (fotoğraflarla) belgelendi ve risk değerlendirme sonucunda "Yüksek" dereceli olduğu belirlenmiştir.

2) Hammadde ve ambalaj malzemelerinin elden geçirilerek sınıflandırılmadığı tespit edilmiş ve kurumsal risk değerlendirme sonucunda "Yüksek" dereceli olduğu belirlenmiştir

3) Gereksiz ve kullanılmayacak malzemelerin ayrı bir tanımlı alanda depolanmadığı ve sevk edilecek son ürünlerin ile iç içe bir ortamda olduğu tespit edilmiş ve kurumsal risk değerlendirme sonucunda "Yüksek" dereceli olduğu belirlenmiştir. 
4) Çalışma alanlarında gerçekleştirilen faaliyet, ürün ve hizmetlerin niteliğine göre gerekli malzemeler düzenlenmediği, iş güvenliği kurallarına uygun olarak tanımlanmadığı tespit edilmiş ve kurumsal risk değerlendirme sonucunda "Yüksek" dereceli olduğu belirlenmiştir.

5) Önemli malzemelerin, kullanım sıklıkları ve kullanım alanlarına göre tanımlandığı tespit edilmiş ve kurumsal risk değerlendirme sonucunda "Yüksek" dereceli olduğu belirlenmiştir.

6) Üretim sahasında bulunan son ürünlerin hijyenik ve temizlik açısından uygun bulunmadığı tespit edilmiş ve kurumsal risk değerlendirme sonucunda "Yüksek" dereceli olduğu belirlenmiştir.

7) Üretim departmanında çalışan mavi yakalı çalışanlar için "Temizlik Sorumluluk Haritasının" belirlenmediği tespit edilmiş edilmiştir. Örneğin; temizlik yapılacak alanlar (stok alanları, raflar, dolaplar, makine ve ekipmanlar, taşıııılar, araç ve gereçler, koridorlar, pencereler, duvarlar, tavanlar) belirlenmediği tespit edilmiş ve kurumsal risk değerlendirme sonucunda "Yüksek" dereceli olduğu belirlenmiştir.

\subsection{S Uygulaması ve Kurumsal Risk Yönetimi}

Bu kapsamda X işletmesinin kurumsal risk yönetim sürecinin, aşağıdaki aşamalardan oluştuğu belirtilmektedir.

1) Öncelikle risk kültürünün benimsenmesi, işletme hedef ve stratejilerinin saptanması. (İç kontrol çalışmasında gerçekleştirilmiştir.)

2) Risklerin neler olduğunun tespit edilip değerlendirilmesi. (İç kontrol çalışmasında gerçekleştirilmiştir.)

3) Dönüşüm aşamasının uygulanması. (Bu adım için $5 \mathrm{~S}$ uygulaması ile mümkün olacaktır ve iç denetçi bunu denetim raporunda iyileştirme önerisi olarak sunmuştur.)

4) Devamlı olarak takip edilmesi ve gözden geçirilmesi. (Bu adım için iç denetim raporunda $5 \mathrm{~S}$ iyileştirme önerisi yapılmış ve düzenli periyotlarda $5 \mathrm{~S}$ süreç denetimi yapılacağını belirtilmiştir.)

İç Denetim Müdürü tarafında, Fabrika Müdürüne ve Yönetim Kurulu Üyesine iç denetim raporu sunulmuş ve yukarıda belirtilen" Yüksek" risk derecesi olan bulgular ile ilgili olarak "Kalite Geliştirme Teknikleri" çatısı altında yer alan "5S" sürecini önerilmiştir. Aksiyon sorumlusu Fabrika Müdürü tarafından kabul edilmiş, Yönetim Kurulu Üyesi tarafından $5 \mathrm{~S}$ eğitim, materyalleri ve diğer harcamalar için onay verilmiştir. . Böylelikle İç Denetim Müdürü tarafından "Kurumsal Risk Yönetim" sürecinin 3. ve 4. aşamaları tamamlanmasını sağlanmıştır.

\subsection{1. İşletmede 5S İle İlgili Yapılan İyileştirmeler}

5S uygulamasının işletme genelinde temel felsefe olarak benimsenmesi için gerekli tüm çalışmaların yapılmasına karar verilmiş ve her bir adımla ilgili detaylı açıklamalar aşağıdaki şekilde yapılmış ve tüm işletme personeli ile paylaşılmıştır. Böylelikle işletmenin her personelinin bu sürece dahil olmasının sağlanması hedeflenmiş ve işletmede meydana gelebilecek hata, israf, gecikme, verimsizlik vb. unsurların minimuma indirilmesi sağlanmıştır.

\section{$\underline{\text { Toparlama/Ayzklama Adımı (S1) }}$}

- 5S Ekipleri tarafından mevcut durum kayıtlarla (video filmlerle veya fotoğraflarla) belgelenir.

- Tüm malzemeleri elden geçirerek sınıflandırmakla işe başlanır.

- Uygulama sonrası ile karşılaştırma yapmak için, tespit bölgeleri tarihleri ile birlikte kayıt altına alınır.

- Gereksiz olan malzemeler belirlenir ve "Kırmızı Etiket" asılır.

- Kırmızı etiket asılan gereksiz malzemeler "Kırmızı Etiket Takip Listesi” ne 5S ekibi tarafından yazılır.

- "Kırmızı Etiket Takip Listesi” onay için 5S kuruluna verilir.

- 5S kurulu “Kırmızı Etiket Takip Listesi”nde yer alan gereksiz malzemeleri değerlendirir. Bu değerlendirme sonunda bu malzemeler için aşağıdaki kararlar verilebilir.
A: Hurda
B: Geçici Depolama
C: Satılacak 


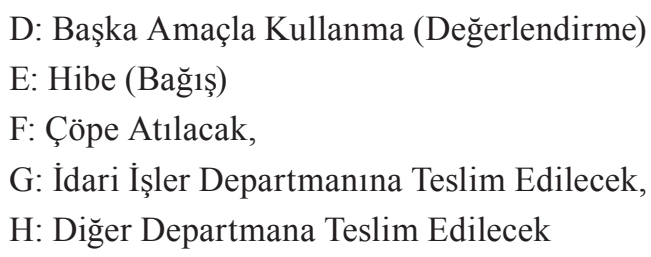

- Gereksiz malzemeler 5S Kurulu kararları doğrultusunda işlem görür.

- "Kırmızı Etiket” asılı olan ve 5S Kurulu tarafından 5S alanından uzaklaştırılmasına karar verilen malzemeler için uygun bir toplanma bölgesi belirlenir. Daha sonra 5S Kurulu, 5S Departman/ekip Lideri ve temsilcileriyle beraber bu malzemelerle ilgili karar verir.

\section{Düzenleme Adımu(S2)}

- 5S ekipleri tarafından 5S uygulama alanlarında alan tanımlamaları iş güvenliği kurallarına uygun olarak yapılır.

- Çalışma alanlarında gerçekleştirilen faaliyet, ürün ve hizmetlerin niteliğine göre gerekli malzemeler 5S ekipleri tarafından belirlenir.

- 5S ekipleri tarafından 5S uygulama alanındaki gerekli malzemeler, kullanım sıklıkları ve kullanım alanlarına göre tanımlanır.

- Kullanılacak hammadde, yarı mamullerin veya techizatın kritik stok seviyeleri belirlenir.

- Bu kapsamda işin kolay yapılmasına, iş güvenliğine, verim ve kalite artışına yönelik iyileştirme fırsatları belirlenir.

- Belirlenen iyileştirme fırsatları kaynak kullanımını gerektirmiyorsa 5S ekibi tarafından uygulamaya alınır. Kaynak gerektiren iyileştirmeler için 5S Kurulundan onay alınır.

\section{$\underline{\text { Temizlik Adımı (S3) }}$}

- 5S ekibi tarafından kirlilik kaynakları belirlenir ve "kirlilik kaynakları haritası” hazırlanır. Kirliliğin önlenmesi ve azaltılması için yollar araştırılır. Gerekiyorsa 5S kurulundan yardım istenir. Amaç önce kirliliği önlemek sonra temizlemektir.

- 5S ekibi tarafından temizlik yapılacak alanlar (stok alanları, raflar, dolaplar, makine ve ekipmanlar, taşıyıcılar, araç ve gereçler, koridorlar, pencereler, duvarlar, tavanlar) belirlenir.

- “Temizlik Sorumluluk Haritası” ve "Temizlik Takvimi” oluşturulur.

- “Temizlik Sorumluluk Haritası”nda 5S uygulama alanlarının yerleşim haritası çizilir. Çizilen harita temizleme bölgelerine ayrılır ve her bölgenin temizliğinden sorumlu olacak kişi belirlenir.

- “Temizlik Takvimi”nde temizlenecek malzemeler/makineler/yer ve temizlik frekansı belirtilir.

- 5S ekibi tarafından 5S uygulama alanlarında gerekli olan temizlik malzeme ve miktarları belirlenir, kullanım yerlerine göre uygun konumlandırılması yapılır.

- Temizlik sıklığı, süresi, gerekli temizlik malzemeleri ve aletleri, aletlerin kullanım şekli, kullanış sıraları ile ilgili gerekirse "Temizlik Talimatı" oluşturulur.

- $\quad$ SS ekibinin katılımı ile belirlenen frekanslara uygun olarak temizlik gerçekleştirilir.

\section{Standartlastırma Adımı (S4)}

- 5S ekipleri tarafından yapılan değişiklikler ve iyileştirmeleri göstermek için hazırlık aşamasında alınan kayıtlar, çekilen videolar veya fotoğrafları gözden geçirilir. Öncesi ve sonrasını gösteren ve kısa açıklamaların olduğu düzenleme yapılarak panoya asılir.

- Her 5S uygulama alanına yönelik olarak ilk üç adım olan ayıklama, düzenleme, temizlik aşamalarının kalıcılığını sağlamak için 5S Kurulu ve 5S Ekibi tarafından standartlar oluşturulur.

\section{Disiplin Adımı (5S)}

- Her 5S uygulama alanına yönelik olarak ilk üç adım olan ayıklama, düzenleme, temizlik aşamalarının kontrolünü için; 
- 5S Ekip Lideri veya günlük olarak atadığı temsilci, her iş günü "5S Günlük Kontrol Formu" nu kullanarak kendi bölgesinde $5 \mathrm{~S}$ uygulamalarının operatörler tarafindan uygulandığını kontrol eder.

- 5S Ekip Lideri veya günlük olarak atadığı temsilci, haftada bir kere "5S Haftalık Kontrol Formu" nu kullanarak kendi bölgesinde 5S uygulamalarının 5S Ekibi tarafından uygulandığını denetler.

- 5S Kurulu tarafindan 5S uygulama alanları ayda bir kez "5S Aylık Denetleme Formu" kullanılarak denetlenir ve değerlendirilir. Değerlendirme puanı $5 \mathrm{~S}$ panosunda yayınlanır.

- Üç aylık değerlendirme sonuçları dikkate alınarak birinci olan ekip, lüzumlu görülmesi halinde 5S Kurulunun belirleyeceği bir ödüle layık görülebilir.

- Birinci olan ekibin duyurusu tüm çalışanların bilgisine sunulur.

- 5S Ekibi, uygulama alanında çalışan veya yeni görev alan personeli eğitmekle görevlidir.

\section{Sonuç}

Değişen piyasa şartları ve hızla gelişen teknolojiyle birlikte, işletmeler artık hem iç ve dış çevrelerine uyum sağlamak, hem de daha doğru karar alabilmek için, birtakım planlama ve yönetim teknikleri benimsemeye başlamışlardır. "İç denetim, kurumsal yönetim, kurumsal risk yönetimi, stratejik yönetim” bunlardan sadece birkaçıdır.

İşletmeler, birden fazla riskle karşılaşabildiklerigibi, tek bir faktör, işletme faaliyetleri için çok büyük risk oluşturabilmektedir. Bu yüzden kurumsal risk yönetimi, işletmeler için gerekliliktir. Çünkü kurumsal risk yönetimi uygulanarak işletme için ortak riskler belirlendiği gibi, nelerin risk, nelerin firsat olduğu da ortaya çıkmaktadır. Böylelikle işletme yönetimi, risk unsurları ile olası etkilerini geniş bir çerçeveden görmüş olurlar.

Çalışanlar açısından bakıldığında, "kurumsal risk yönetimi sürecindeki sorumluluklarının ve kurumlarına sağlayabilecekleri katkının farkında oldukları sürece çok sayıda bakış açısı ve tecrübe bu sürecin gelişmesini olumlu yönde etkileyecektir" Kurumsal Risk Yönetimi, iç denetimle birlikte hareket etmesi gereken bütünleşik bir süreç olup, hem işletme faaliyetlerine, hem de işletmenin mali durumuna fayda sağlar.

Tüm bu gelişmelerle birlikte bağımsız bir güvence veren iç denetimin de önemi giderek artmıştır. Bu bağlamda; "saydamlık ve hesap verilebilirlik ihtiyacını karşılayabilmek için geçmişi analiz edip geleceğe dönük projeksiyonlar öngörebilen, mevcut sorunları olduğu kadar potansiyel firsatları da gösterebilen, süreç odaklı değerlendirme yapabilen, yönetimin taleplerini karşılayabilecek şekilde risk odaklı bakış açısına ve gelişen teknolojiyi etkin kullanabilecek beceriye sahip olan ve kurum içi danışmanlık görevini yerine getirebilecek bir iç denetim fonksiyonu ve denetçiler, çalıştıkları kurumların başarısına önemli katkı sağlamaktadırlar”

Risk odaklı iç denetim sisteminin olabilmesi için, risk yönetiminin ve iç kontrol sisteminin etkin olması gerekir. Ayrıca yönetim bilgi sistemlerini güçlendirilip uygunluk değerlendirme birimleri oluşturulmalıdır. Tüm bunlar, öncelikle bir işletmenin kurumsal yönetime sahip olmasından ve işletme içindeki yapıların yeniden düzenlenmesinden geçmektedir. Çalışmada belirtilen $5 \mathrm{~S}$ uygulamalarında temel amaç, şirket içinde verimliliği arttıracak malzeme, ekipman, işgücünden en iyi şekilde faydalanılmasıdır. Bununla birlikte 5S'in farkları anında fark edebilmeye ve kilit performans göstergelerine olumlu etkisi tartışılmazdır. 5S’te devamlı gözlem yapıldığ için işletme içinde oluşan ya da oluşabilecek riskler derhal tespit edilecek ve giderilecektir. Böylelikle iç denetimin temel unsurlarından biri olan "risk yönetimi” unsuru 5S uygulaması ile en iyi şekilde işliyor ve tüm işletme personelinin de sürece dahil olmasından kaynaklı olarak işletmeye değer katma fonsiyonunu da en iyi şekilde yerine getiriyor olacaktır.

Süreçlerle ilgili olarak 5S uygulaması herbir detayı ele alan bir uygulama olduğundan her ne kadar ilk uygulama aşamasında özellikle iş adımlarının detaylı belirlenmesinden dolayı zor gibi görünse de böylesine detaylı bir uygulama ile işletme tüm yönlerden daha hassas bir denetime tabi olacağından faydası tartışılamazdır. Böylelikle kurumsal risk yönetiminde 4T yaklaşımı "tespit, tahlil, tedbir ve takip" olarak sıralanan sürecin de en iyi şekilde yönetilmesine katkı sağlayacaktır. 
Çalışmada detayları ile açıklanan 5S uygulamasından da görüldüğü gibi, iç denetim ve kurumsal risk yönetimi zorlu süreçler olup, doğru bir şekilde uygulanması için çaba ve kararlılık gerekmektedir. Gerek iç denetim, gerekse risk yönetimi, işletmenin tamamını kapsayacak şekilde tasarlanıp uygulamaya konmalıdır. Genel bir çerçeve çizilerek, işletmeye uygun şekilde düzenlenmesi, işletmenin kendi ihtiyaçlarına yönelik olması ve işletmenin kendi özel yapısıyla uyumlu olması gerekir.

Finansal Destek: Yazarlar bu çalışma için finansal destek almamışlardır.

\section{Kaynakça}

Akçakanat, (2012), “ Kurumsal Risk Yönetimi Ve Kurumsal Risk Yönetim Süreci”, Süleyman Demirel Üniversitesi Vizyoner Dergisi, Cilt:4, Say1:7, ss.30-46, Isparta

Arslan, I. (2008), “Kurumsal Risk Yönetimi”, Maliye Bakanlığı Strateji Geliştirme Başkanlığı, Yayınlanmamış Uzmanlık Tezi, Ankara Aysan, M. A. (2007). "Muhasebe ve Kurumsal Yönetim”, Muhasebe ve Finansman Dergisi, S.35, ss.17-24.

Bolgün, E. Ve Akçay, B. (2003), Risk Yönetimi, İstanbul: Scala Yayıncılık

Börekçi, E. (2004), “Bankacılıkta Faiz Ve Döviz Riski Yönetimi”, Yayınlanmamış Yüksek Lisans Tezi, İstanbul Teknik Üniversitesi Fen Bilimleri Enstitüsü, İstanbul

Çevrimiçi: https://yalindanisman.com/yalin-yazarlar-5s-uygulama-yaklasimi-ve-tarihi/

Demirbaş, M. (2005), “İç Kontrol Ve İç Denetim Faaliyetlerinin Kapsamında Meydana Gelen Değişimler”, İstanbul Ticaret Üniversitesi Sosyal Bilimler Dergisi, Say1: 7 (Bahar), ss. 167-188.

Doyrangöl, N.C., (2002), “İşletme Çevresindeki olumsuz Gelişmeler Karşısında

İç Denetimin Yeri ve Önemi”, Mali Çözüm Dergisi, Y11:12, Sayı:60, Sayı:1,(ss.1-7).

Emhan, A. (2009), “Risk Yönetim Süreci Ve Risk Yönetmekte Kullanılan Teknikler”, Atatürk Üniversitesi İktisadi ve İdari Bilimler Dergisi, Cilt: 23, Sayı: 3, ss.209-220, Erzurum

Gönen, S., Çelik, M., 2005, "Rekabet Üstünlüğü Sağlamada İç Denetim Ve İnsan Kaynakları Yönetiminin Stratejik Ortaklığı”, Ege Akademik Bakış - Ekonomi, İşletme, Uluslararası İlişkiler ve Siyaset Bilimi Dergisi, Cilt: 5, Sayı: 1, Ocak-Temmuz, ss. 41-46, İzmir

Güneş, Ş. ve Teker, S. (2010). "Türk enerji sektöründe kurumsal risk yönetimi

Farkındalı̆̆ı”. Doğuş Üniversitesi Dergisi, Sayı:11 (1), ss.64-76.

IIA, (2009), “The Institute of Internal Auditors, Glossary of Terms”, http://www.theiia.org, Erişim: 12.11.2018

Kızılboğa, R. (2012). “Geleneksel Risk Yönetiminden Kurumsal Risk Yönetim Sistemine Geçiş”. Atatürk Üniversitesi Sosyal Bilimler Enstitüsü Dergisi, Say1:16 (3), ss.297-316, Erzurum.

Kurnaz, N., Çetinoğlu, T., (2010), İç Denetim Güncel Yaklaşımlar, Umuttepe Yayınları, No: 33, Kocaeli

Merna, T. Ve Al-Thani, F. (2008), Corporate Risk Management, Second Edition, John Wiley And Sons Ltd., England

Osada,T.,(1991), The 5S's: Five Keys to a Total Quality Environment, Asian Productivity Organization

Pehlivanl1, D. (2011). Kurumsal Risk Yönetimi Uygulamaları, İstanbul: Beta Kitap

Saka, T. ve Uğural,A. (2009), Kurumsal Risk Yönetimi, Doğuş ve Sabancı Holding TUSİAD Sunumu,

Tekin, M. , Arslandere, M., Etlioğlu, M. , Tekin, E. (2018). “Büyük Ölçekli Bir İşletmede 5S Uygulaması”. International Journal of Social And Humanities Sciences $2 / 1,106-122$

Yörüker, S. (2004), "Başka Ülke Örnekleri Temelinde Kontrol, Denetim, Teftiş ve Soruşturma:Kavramsal Bir Çerçeve”, TESEV Denetim Çalıştayı İkinci Toplantısı, Ankara 